organic matter caused by death and decay of zooplankton. Again a high $p \mathbf{H}$ in the months of February and March was observed to be accompanied by the blooming of Myxophyceae, causing an increase in phytoplankton. The lowest $p H$ values were obtained during May and June, when there was an abundance of zooplankton and lack of phytoplankton.

It has also been observed that high $p H$ values of water coincide with low values for carbon dioxide, and with the phytoplankton peaks, while low $p \mathbf{H}$ values coincide with high concentration of carbon dioxide in water during the zooplankton peak periods. This appears to be due to the fact that increase in phytoplankton causes photosynthetic activity which uses up dissolved carbon dioxide, and thus the $p \mathbf{H}$ values are raised in February and March. In the summer months, due to the concentration of aquatic animals (fishes, molluses, etc.) in the decreased amount of water, combined with the abundance of zooplankton, the concentration of carbon dioxide increases and $p \mathrm{H}$ values reach a minimum. It is thus clear that, generally, high $p \mathrm{H}^{\prime}$ means high phytoplankton and low zooplankton; whereas low $p \mathrm{H}$ means low phytoplankton and high zooplankton in ordinary circumstances.

It has recently been observed (Das, unpublished work) that more fishes are present in natural lakes with a $p \mathrm{H}$ range of $7 \cdot 2-8 \cdot 2$, but decline rapidly in highly alkaline waters which remain above $p \mathbf{H} 9$. As no Indian eutrophic lakes have been found with a $p \mathrm{H}$ less than $7 \cdot 2$, fish fertility appears to be indirectly dependent on the $p H$ of such bodies of water. Thus a change of environment due to change of $p \mathrm{H}$ may affect the productivity of fish in fresh-water lakes and tanks. This aspect is now being studied.

Department of Zoology,

S. M. DAS

University of Lucknow.

${ }^{2}$ Das, S. M., et al., Proc. Nat. Acad. Sci. (India), 26 (1); 26 (4); 27 (3); 29 (4); 29 (4) (1956-59).

${ }^{2}$ Chacko, P. I., et al., Symp. Marine and Freshwater Plankton in the Indo-Pacific, Bangkok (Unesco, 1954).

${ }^{3}$ Alikunhi, K. H., et al., Ind. J. Fisheries, 2 (1955).

\section{Littoral Interstitial Species from Anglesey representing Three Families new to Britain}

IN 1956 a brief investigation by Dr. B. Swedmark of beaches in the Anglesey area revealed a welldeveloped microfauna. A more intensive survey is now in progress, and many typical interstitial species have been found.

Some of the most interesting recent discoveries have been made in the low-water neap zone at Traeth Bychan, a gently sloping beach of coarse sand on the east coast of Anglesey. Three small molluscs belonging to the Pseudovermidae, a nudibranch family new to Britain, have been found in this habitat. They resemble Pseudovermis schulzi Marcus and Marcus more closely than any other species described. All three measured 3-3.5 mm. in length when extended, but were unfortunately immature. The shape of the radular plates together with the presence of eyes seem to confirm the identification as $P$. schulzi, but there were as many as fifteen body papillæ and an equal number of cnidosacs (Fig. 1). A maximum of five papillæ was given as a diagnostic feature in the original description. The cnidoblasts were all of one type, penetrants $5.5 \mu$ long and $4 \mu$ broad with a thread up to $70 \mu$ long when discharged.

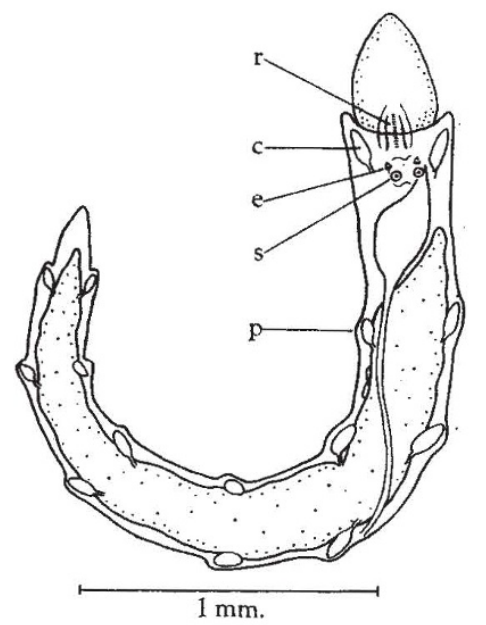

Fig. 1. Pseudovermis sp. from Anglesey. Dorsal view. $c$, cnidosac $e$, eye; $p$, body papilla; $r$, radula; $s$, statocyst

They were found to be identical in size and structure with those of the hydrozoan Halammohydra vermiformis Swedmark and Teissier, which has been found in the same area of beach. It is thus highly probable that this Pseudovermis species preys upon $H$. vermiformis. Apart from the suggestion by Dr. E. Marcus that the Brazilian Pseudovermis salamandrops Marcus derives its nematocysts from Psammohydra nanna, Schulz ${ }^{1}$, no previous information concerning the food of pseudovermids is available.

A second species of Halammohydra, H. schulzei Remane, has been found in the Menai Straits among coarse shell gravel exposed at low water on spring tides. The family Halammohydridae had not previously been recorded from Britain, but an unidentified species has since been reported from the Isles of Scilly ${ }^{2}$.

Last August a sample of sand from Traeth Bychan which contained several young $H$. vermiformis yielded a curious interstitial annelid. Further examples of this animal recovered recently prove it to be the sedentary polychæte Psammodrilus balanoglossoides Swedmark belonging to the Psammodrilidae Swedmark. This constitutes the third new family from this one habitat to be added to the British fauna list.

Marine Biology Station,

$$
\text { P. J. S. BOADEN }
$$

Menai Bridge, Anglesey.

${ }^{1}$ Marcus, E. du B.-R., Bol. Fac. Filos. Cienc., Zool., 18 (1953). ${ }^{2}$ Harvey, L. A., and Wells, J. B. J., Nature, 189, 944 (1961).

\section{Response to Series of Subliminal Stimuli; an Ethological Method for investigating the Properties of Nervous Systems}

QUEEN ants of genus Formica react to mechanical disturbance of the nest by running downwards to the deepest chambers. In laboratory colonies a series of shocks could result in a reaction, although one similar shock was too small to produce any visible effect.

To investigate this further, three separate queens of $F^{\prime}$. fusca L., without workers, were subjected at the same time to series of nearby taps on the bench with constant periodicity throughout each series and constant strength throughout this work. The periodicity was changed for different series and the 